\title{
Stimulation of mucosal prostaglandin synthesis in human stomach and duodenum by antacid treatment
}

\author{
G PRECLIK, E F STANGE, K GERBER, G FETZER, H HORN, \\ AND $H$ DITSCHUNEIT \\ From the Department of Internal Medicine II, University of Ulm, Ulm, West Germany
}

SUMmary The effect of a low dose antacid treatment on mucosal prostaglandin metabolism was studied in 15 healthy volunteers. A daily dose of $46 \mathrm{mmol}(=138 \mathrm{mval}) \mathrm{Al}(\mathrm{OH})_{3}$ and $42 \mathrm{mmol}(=84$ mval) $\mathrm{Mg}(\mathrm{OH})_{2}$ with a titrated in vitro neutralising capacity of $272 \mathrm{mval}$ of $\mathrm{H}^{+}$was given for three weeks. Total prostaglandin formation and the prostaglandin profile as well as the degradation of $\mathrm{PGE}_{2}$ were assayed by incubating homogenates of endoscopic biopsies from antral and duodenal mucosa with the precursor $\left({ }^{14} \mathrm{C}\right)$ arachidonic acid. Total prostaglandin synthesis in antrum $(623$ (110) $\mathrm{pmol} / \mathrm{mg}$ protein) and duodenum (432 (72) $\mathrm{pmol} / \mathrm{mg}$ ) was stimulated after three weeks administration of low dose antacids by $176 \%(p<0.05)$ and $154 \%(p<0.05)$, respectively. An untreated control group exhibited no significant changes. In contrast, the prostaglandin profile showed only a small increase of the prostacyclin metabolite 6-keto PGF $_{1 \mathrm{a}}(\mathrm{p}<0.05)$ at the expense PGD $_{2}$. PGE 2 catabolism was unaffected. This enhanced activity of mucosal prostaglandin cyclooxygenase might represent one possible mechanism of action of a low dose antacid treatment.

Antacids heal peptic ulcers at doses ${ }^{12}$ too low to significantly affect gastric acidity. ${ }^{3}$ Antacids may therefore have cytoprotective effects and this is supported by some animal experiments. ${ }^{46}$ Antacids release mucosal prostaglandins, ${ }^{5}$ which could mediate this protective effect. ${ }^{7}$ In this study prostaglandin synthesis in homogenates of endoscopic biopsies was measured in response to antacid administration.

Methods

STUDY DESIGN

Fifteen healthy volunteers were treated for three weeks with an antacid (Maalox 70, $4 \times 10 \mathrm{ml}$ ), containing $46 \mathrm{mmol}(=138 \mathrm{mval}) \mathrm{Al}(\mathrm{OH})_{3}$ and 42 $\mathrm{mmol}(=84 \mathrm{mval}) \mathrm{Mg}(\mathrm{OH})_{2}$ per day. The in vitro neutralising capacity amounted to $272 \mathrm{mval} /$ day.

\footnotetext{
Address for correspondence: Eduard F Stange, MD, Abt Innere Medizin II Universitätsklinikum Ulm, Oberer Eseisberg, Robert-Koch-Strasse, D-7900 Ulm, West Germany.

Accepted for publication 29 June 1988.
}

A separate group of eight volunteers remained untreated and served as controls. Three mucosal biopsies were taken endoscopically from both the prepyloric antrum and duodenal bulb at the start and end of the study period. The last antacid was taken at $1000 \mathrm{pm}$ and the volunteers were fasted overnight before endoscopy at $900 \mathrm{am}$. None had a history of peptic ulcer disease and the endoscopy findings were completely normal. Histological examination revealed normal mucosa in all volunteers except for three with minimal surface gastritis. No smoking and no other medication was allowed and the volunteers maintained a normal diet without specific standardisation during the study.

\section{DETERMINATION OF ENDOGENOUS}

PROSTAGLANDIN SYNTHESIS

For each assay three biopsies $(1.5(0.5) \mathrm{mg}$ protein) were added to $600 \mu \mathrm{l}$ buffer and were immediately homogenised with a Potter-Elvehjem grinder at $4^{\circ} \mathrm{C}$. The prostaglandin synthesis was determined as described previously for rabbit mucosa. ${ }^{8}$ Protein content was measured according to Lowry et al. ${ }^{9}$ 
$\left(1{ }^{14} \mathrm{C}\right)$-arachidonic acid $(1 \mathrm{mCi} / \mathrm{mmol})$ and $\left({ }^{3} \mathrm{H}\right)$ $\mathrm{PGE}_{2}$ were purchased from New England Nuclear Chemicals GmbH (Dreieich, West Germany). Unlabelled arachidonic acid, adrenaline and the standard prostaglandins were supplied by Sigma Chemical Co (Deisenhofen, West Germany).

In brief, $50 \mathrm{mM}$ Tris buffer ( $\mathrm{pH} 8 \cdot 0$ ) containing $1 \mathrm{mM}$ epinephrine as a cofactor was used for homogenisation and assay. The assay was started immediately after homogenisation by adding $0.5 \mathrm{ml}$ tissue homogenate to the same volume of a substrate buffer solution, containing $160 \mathrm{nmol}\left({ }^{14} \mathrm{C}\right)$-labelled arachidonic acid $(0 \cdot 25 \mu \mathrm{Ci})$. After 20 minutes of incubation at $37^{\circ} \mathrm{C}$ the reaction was stopped with $0.5 \mathrm{ml} 1.0 \mathrm{~N}$ acetic acid.

After extraction into $7.5 \mathrm{ml}$ of a chloroformmethanol solution $(2: 1$, by vol) the primary prostaglandins $D_{2}, E_{2}, F_{2 a}$, and the stable degradation products of thromboxane $A_{2}$ and prostacyclin, thromboxane $B_{2}$ and 6-keto prostaglandin $F_{1 a}$, respectively, were separated according to Goswami et al,$^{10}$ using chloroform-isopropanol-ethanol-formic

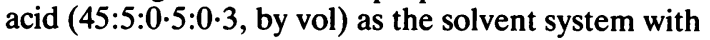
repeat development. The prostaglandins $A_{2}$ and $B_{2}$ (comigrating) and the prostaglandin $\mathrm{E}_{2}$ metabolites 15-keto $E_{2}$ and 13,14-dihydro-15-keto $E_{2}$ (EM) were isolated from the same sample by a parallel chromatography according to Korte et al ${ }^{11}$ with chloroform-methanol-acetic acid-water (95:5:1:0.2, by vol) as the solvent system using a single development. After visualisation with iodine vapour the

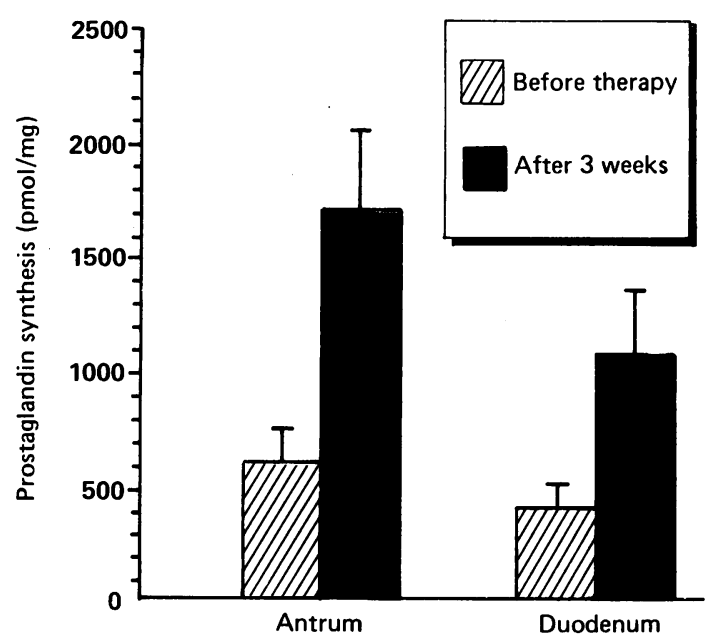

Figure Prostaglandin synthesis from $\left({ }^{14} \mathrm{C}\right)$ arachidonic acid by antral and duodenal mucosal homogenate. Measurements were made in 15 volunteers, before and after administration of a low dose antacid regimen for three weeks. The results represent means (SE). bands were scraped and the newly synthesised, $\left({ }^{14} \mathrm{C}\right)$ labelled prostanoids were counted with a liquid scintillation counter, using Lumagel as scintillation fluid.

After subtraction of blanks the amount of each single prostaglandin formed during the incubation was calculated from the counts measured in the corresponding band and the specific radioactivity of the labelled arachidonic acid. Values were normalised to the protein content. Total prostaglandin synthesis was calculated from the sum of all the primary prostanoids isolated. Statistical calculations were performed using the Wilcoxon's test for paired samples.

The kinetic properties of the endogenous prostaglandin synthesis in human mucosa were similar to the rabbit. ${ }^{8}$ The reaction was linear with respect to protein concentration and curvilinear with respect to time up to 20 minutes. Substrate saturation was achieved at an arachidonic acid concentration of $80 \mu \mathrm{M}$.

\section{Results}

Total prostaglandin synthesis by antral mucosal biopsies was slightly higher than that by duodenal biopsies $(\mathrm{p}<0 \cdot 05$, Figure). Prostaglandin formation by mucosal homogenates significantly increased after the three weeks antacid regimen; total prostaglandin synthesis was stimulated by $176 \%$ in the antrum and by $154 \%$ in the duodenum $(p<0 \cdot 05)$. In contrast, prostaglandin synthesis in the untreated control group $(n=8)$ was not changed significantly in antrum (853 (123) v 1263 (111) $\mathrm{pmol} / \mathrm{mg}$, mean (SE)) or duodenum (500 (79) $v 650$ (47) $\mathrm{pmol} / \mathrm{mg}$ ).

As shown in the Table, the prostaglandin profile was only marginally affected by antacid treatment. The only significant change was the increased proportion of 6-keto $F_{1 a}(p<0.05)$, the metabolite of prostacyclin, at the expense of $\mathrm{PGD}_{2}$. In the controls the prostaglandin profile was constant.

Both major metabolites of $\mathrm{PGE}_{2}, 15$-keto $\mathrm{PGE}_{2}$ and 13,14-dihydro-15-keto $\mathrm{PGE}_{2}$ accounted for only 2.6 to $6.3 \%$ and 0.5 to $4.5 \%$, respectively, of total prostaglandins synthesised in both the antral and duodenal homogenates. There was no significant difference between pre and post-treatment values.

\section{Discussion}

The effects of an antacid treatment on the endogenous prostaglandin metabolism in human antral and duodenal mucosa was investigated, using in vitro incubation of mucosal homogenate with exogenous, $\left({ }^{14} \mathrm{C}\right)$-labelled arachidonic acid as precursor. The method determines the mucosal capacity to synthe- 
Table Effects of antacid treatment on prostaglandin profile in human antral and duodenal mucosa

\begin{tabular}{|c|c|c|c|c|c|c|c|}
\hline & & \multicolumn{6}{|l|}{$\%$ of total } \\
\hline & & $A 2 / B 2$ & D2 & $E 2$ & $F 2 a$ & 6-keto Fla & $T \times B 2$ \\
\hline \multirow[t]{2}{*}{ Antrum/ } & before & $21 \cdot 4(3.4)$ & $9 \cdot 6(1 \cdot 8)$ & $25 \cdot 9(2 \cdot 1)$ & $30 \cdot 2(3 \cdot 2)$ & $4 \cdot 8(0 \cdot 7)$ & $8 \cdot 1(1 \cdot 0)$ \\
\hline & after & $25 \cdot 7(2 \cdot 3)$ & $7.9(0.7)^{*}$ & $22.7(1.5)$ & $27 \cdot 1(2 \cdot 0)$ & $7 \cdot 5(0 \cdot 8)^{*}$ & $10 \cdot 0(0 \cdot 8)$ \\
\hline \multirow[t]{2}{*}{ Duodenum/ } & before & $17 \cdot 9(3 \cdot 1)$ & $15 \cdot 1(3 \cdot 0)$ & $27 \cdot 2(3 \cdot 4)$ & $29 \cdot 1(4 \cdot 3)$ & $4 \cdot 3(1 \cdot 1)$ & $6.4(1.0)$ \\
\hline & after & $24 \cdot 3(3 \cdot 0)$ & $6 \cdot 6(1 \cdot 2)$ & $25 \cdot 8(2 \cdot 4)$ & $27 \cdot 7(2 \cdot 2)$ & $7 \cdot 2(1 \cdot 0)$ & $8 \cdot 3(1 \cdot 1)$ \\
\hline
\end{tabular}

Proportion of various prostaglandins formed from $\left({ }^{14} \mathrm{C}\right)$ arachidonic acid by mucosal homogenate before and after therapy, as detailed in Figure 1 . The results shown are the means (SE) of the percentage distribution in 15 volunteers.

${ }^{*} \mathrm{p}<0.05 v$ respective control before treatment.

sise prostanoids and the complete prostaglandin profile. In addition, the catabolism of newly synthesised $\mathrm{PGE}_{2}$ was also measured. As discussed in a previous review article, ${ }^{12}$ this technique is probably less subject to experimental artefacts than other methods based on content or release of mucosal prostaglandins. The method has shown a specific defect of prostaglandin synthesis in duodenal ulcer patients. ${ }^{13}$

After three weeks of low dose antacid administration the capacity of the mucosa to synthesise prostaglandins in the antrum and duodenum was significantly raised, whereas only minor differences in the prostaglandin profile were detectable. This rise of the prostaglandin synthesising capacity is in accordance with the enhanced $\mathrm{PGE}_{2}$ content of or release by the mucosa in rat and human stomach after antacid treatment. ${ }^{4514}$ This study shows that increased $\mathrm{PGE}_{2}$ secretion is not only the result of a short lived prostaglandin release but is also related to an enhanced synthetic capacity of the mucosa. Measurable effects probably are independent from endogenous substrate and dietary intake of polyunsaturated fatty acids because exogenous arachidonic acid is added to the assay at saturating concentrations. Changes of the endogenous cofactor supply of the cyclooxygenase also are unlikely to be responsible for this finding because adrenaline was added to the assay buffer as a cofactor at an optimal effective concentration. ${ }^{12}$ Similarly, reduced degradation of the newly synthesised prostaglandins was excluded at least for $\mathrm{PGE}_{2}$. The increased synthetic capacity appears to be related to an elevated activity of prostaglandin cyclooxygenase, ${ }^{5}$ rather than subsequent enzymatic steps, because the complete prostaglandin profile, including the proportion of thromboxane $\mathbf{B}_{2}$, was essentially unchanged. It remains unclear whether this effect is indirectly caused by a regulatory response to antacid induced alterations in mucosal integrity including low grade superficial damage by antacid crystals and leucocyte accumulation ${ }^{16}$ or by a more direct effect of antacid compounds on the enzymatic complement of the epithelial cells.

The observed increase in mucosal prostaglandin synthesising capacity was a prolonged effect of antacids, because there was a 12 hours interval between the last antacid intake and the endoscopy.

Low dose antacids therefore resemble bismuth compounds and sucralfate, whose cytoprotective action is independent of acid binding or secretion and is related to an increase of mucosal PG $\mathrm{E}_{2}$ generation. ${ }^{17}$

Whether this antacid effect is of any therapeutic significance for patients with erosive gastritis or peptic ulcer disease is unclear because the role of the endogenous prostaglandin synthesis in these diseases is still unknown.

Parts of this work were published previously in abstract form (Gastroenterology 1987; 92: 1579).

\section{References}

1 Berstad A, Rydning A, Aadland E, Kolstad B, Frislid K, Aaseth J. Controlled clinical trial of duodenal ulcer healing with antacid tablets. Scand J Gastroenterol 1982; 17: 953-9.

2 Lam SK, Lam KC, Lai CL, Yeung CK, Yam LYC, Wong WS. Treatment of duodenal ulcer with antacid and Sulpiride. A double-blind controlled study. Gastroenterology 1978; 76: 315-22.

3 Blum AL. Stellung der Antacida in der modernen Ulcustherapie. Dtsch Med Wochenschr 1985; 110: 3-7.

4 Szelenyi I, Postius S, Engler H. Evidence for a functional cytoprotective effect produced by antacids in the rat stomach. Eur J Pharmacol 1983; 88: 403-6.

5 Szelenyi I, Postius S. Further evidence for gastroprotection induced by aluminium hydroxide in the rat. Z Gastroenterol 1986; 24: 717-21.

6 Hagel J, Renner H, Hirsch M, et al. Gastric cytoprotection by antacids and papaverine in rats. Hepatogastroenterology 1982; 29: 271-4.

7 Robert A, Nezamis JE, Lancaster C, Hanchar AJ. Cytoprotection by prostaglandins in rats. Prevention of gastric necrosis produced by alcohol, $\mathrm{HCl}, \mathrm{NaOH}$, 
hypertonic $\mathrm{NaCl}$, and thermal injury. Gastroenterology 1979; 77: 433-43.

8 Preclik G, Stange EF, Arnold D, Kraft O, Schneider A, Ditschuneit $\mathrm{H}$. Prostaglandin synthesis along the gastrointestinal tract of the rabbit: Differences in total synthesis and profile. Prostaglandins 1987; 33: 459.

9 Lowry DH, Rosebrough NJ, Farr AL, Randall RJ. Protein measurement with the Folin phenol reagent. J Biol Chem 1951; 193: 265-75.

10 Goswami SK, Kinsella JE. Separation of prostaglandins A, B, D, E, F, thromboxane and 6-keto prostaglandin F1a by thin-layer chromatography. J Chromatogr 1981; 209: 334-6.

11 Korte K, Casey ML. Separation of prostanoids by onedimensional thin-layer chromatography. $J$ Liquid Chromatogr 1983; 6: 55-62.

12 Stange EF, Preclik G, Ditschuneit H. Prostaglandin biosynthesis in gastroduodenal mucosa: Methodological difficulties and their implications. Scand J Gastroenterol 1986; 21 [suppl 125]: 121-5.
13 Ahlquist DA, Dozois RR, Zinsmeister AR, Malagelada J-R. Duodenal prostaglandin synthesis and acid load in health and in duodenal ulcer disease. Gastroenterology 1983; 85: 522-8.

14 Reimann H-J, Schmidt U, Wendt P, et al. Die Wirkung von Antacida auf den Gehalt von Gewebshistamin und Prostaglandinen (PG E2) in der Magenmucosa. Fortschr Med 1984; 102: 25-6.

15 Marshall PJ, Kulmacz RJ, Lands WEM. Constraints on prostaglandin biosynthesis in tissues. $J$ Biol Chem 1987; 262: 3510-7.

16 Tarnawski A, Hollander D, Cummings D, Krause WJ, Gergely H, Zipser RD. Are antacids neutralizers only? Histologic, ultrastructural and functional changes in normal gastric mucosa induced by antacids. Gastroenterology 1984; 86: 1276.

17 Konturek SJ, Radecki T, Piastucki I, Brzozowski T, Drozdowicz D. Gastrocytoprotection by colloidal bismuth subcitrate (De-Nol) and sucralfate. Role of endogenous prostaglandins. Gut 1987; 28: 201-5. 